\title{
Editorial for the Special 100th Anniversary Issue
}

\section{(C) Kiel Institute 2013}

In 1913 the German economist Bernhard Harms, also founder of the Kiel Institute for the World Economy, started a new journal titled Weltwirtschaftliches Archivthe world's first field journal in international economics. While initially all articles in the journal were in German language, over the years more and more contributions were published in English, and the name of the journal was changed to Review of World Economics/Weltwirtschaftliches Archiv. Today all articles are in English and feature contributions from economists all over the globe.

The papers in this "Special 100th Anniversary Issue" reflect a broad scope of today's research in international economics. Gene Grossman surveys recent studies on the effects of international trade in models with heterogeneous workers. Giuseppe Bertola and Anna Lo Prete study how policy channels contribute to the link between economic openness and financial development. Jozef Konings and Hylke Vandenbussche provide firm-level evidence of a negative effect of antidumping protection on exports. Rebecca Tomasik finds empirical support for time zone-related continuity effects on international trade. Sanne Hiller analyses the impact that the employment of immigrants has on export sales. Annette Schminke and Johannes van Biesebroeck use export market performance to evaluate regional preferential policies in China. Dierk Herzer and Peter Nunnenkamp provide evidence on the relation between FDI and income inequality in Europe. Jeffrey Frankel and Jesse Schreger show that the fiscal rules in the eurozone have contributed to over-optimistic official forecasts.

We would like to express our gratitude to these and all other authors who have contributed to the journal in the past, and to the many excellent referees whose reports have been of great importance for the high quality of articles published in the journal. We would also like to thank our publisher Springer for the smooth and efficient publication process over many years.

Dennis Snower

Editor
Harmen Lehment

Managing Editor 